\title{
The Relationship Between the PPARס-87T>C Polymorphism and Colorectal Cancer Risk in a Chinese Han Population
}

\section{ZongGuang Zhou ( $287029577 @ q q . c o m$ )}

Sichuan University West China Hospital https://orcid.org/0000-0002-7616-1199

\section{Bo Dong}

Shanxi Provincial Peoples Hospital

\section{Lie Yang}

Sichuan University West China Hospital

\section{Bin Zhou}

Sichuan University West China Hospital

\section{Dan Zhang}

Sichuan University West China Hospital

\section{Wen-Jian Meng}

Sichuan University West China Hospital

\section{Mo-Jin Wang}

Sichuan University West China Hospital

\section{Yong Liu}

Sichuan University West China Hospital

\section{Yuan Li}

Sichuan University West China Hospital

\section{Xiao-Feng Sun}

Linköping University: Linkopings universitet

\section{Research article}

Keywords: PPARס, Colorectal cancer (CRC), Single nucleotide polymorphism (SNP), Polymerase chain reaction-restriction fragment length polymorphism (PCR-RFLP)

Posted Date: October 14th, 2020

DOI: https://doi.org/10.21203/rs.3.rs-91156/v1

License: (c) (1) This work is licensed under a Creative Commons Attribution 4.0 International License. Read Full License 


\section{Abstract}

\section{Background}

Peroxisome proliferator-activated receptor- $\beta / \delta(P P A R \beta / \delta)$ is a transcription factor that has the potential to be associated with the development of colorectal cancer (CRC). However, the exact role of PPARס in the context of CRC development remains to be clarified. This present study was thus designed to understand the association between CRC risk and the PPAR $\delta-87 T>C$ single nucleotide polymorphism (SNP) in a western Chinese Han population.

\section{Methods}

The PPARס-87T >C (rs2016520) polymorphism was analyzed via the polymerase chain reaction-restriction fragment length polymorphism (PCR-RFLP) approach in 410 CRC patients and 496 frequency-matched healthy controls via a case-control study design. Relationships between PPARס-87T $>C$ polymorphisms and clinicopathological parameters were assessed using Pearson chi-squared tests or Fisher's exact test, Odds ratios (ORs) and 95\% confidence intervals (Cls) were used to evaluate the association between the PPARס-87T >C SNP and CRC risk. Results

We observed significant differences in genotypic frequencies when comparing CRC patients (TT 62\%, TC $32 \%$, and CC 6.1\%) and controls (TT 65.5\%, TC 32,3\%, and CC 22\%). In addition, PPARס-87T >C genotype was associated with tumor differentiation $(P=0.033)$, but was unrelated to clinicopathological parameters in CRC patients. An unconditioned logistic regression model analysis revealed that individuals harboring the homozygous $\mathrm{CC}$ genotype exhibited an elevated $\mathrm{CRC}$ risk relative to those harboring the TT genotype $(\mathrm{OR}=2.931,95 \% \mathrm{Cl}=1.41-6.08 ; \mathrm{P}=0.004)$.

\section{Conclusions}

Our findings indicate that the homozygous PPAR $\delta-87 T>C$ CC genotype is associated with an elevated CRC risk as compared to the homozygous TT genotype, indicating that PPAR $\delta-87 T>C$ polymorphisms have the potential to serve as a marker for CRC risk. Keywords PPARס, Colorectal cancer (CRC), Single nucleotide polymorphism (SNP), Polymerase chain reaction-restriction fragment length polymorphism (PCR-RFLP)

\section{Full Text}

This preprint is available for download as a PDF.

\section{Tables}

Due to technical limitations, table 1 to 4 is only available as a download in the Supplemental Files section. 


\section{Figures}

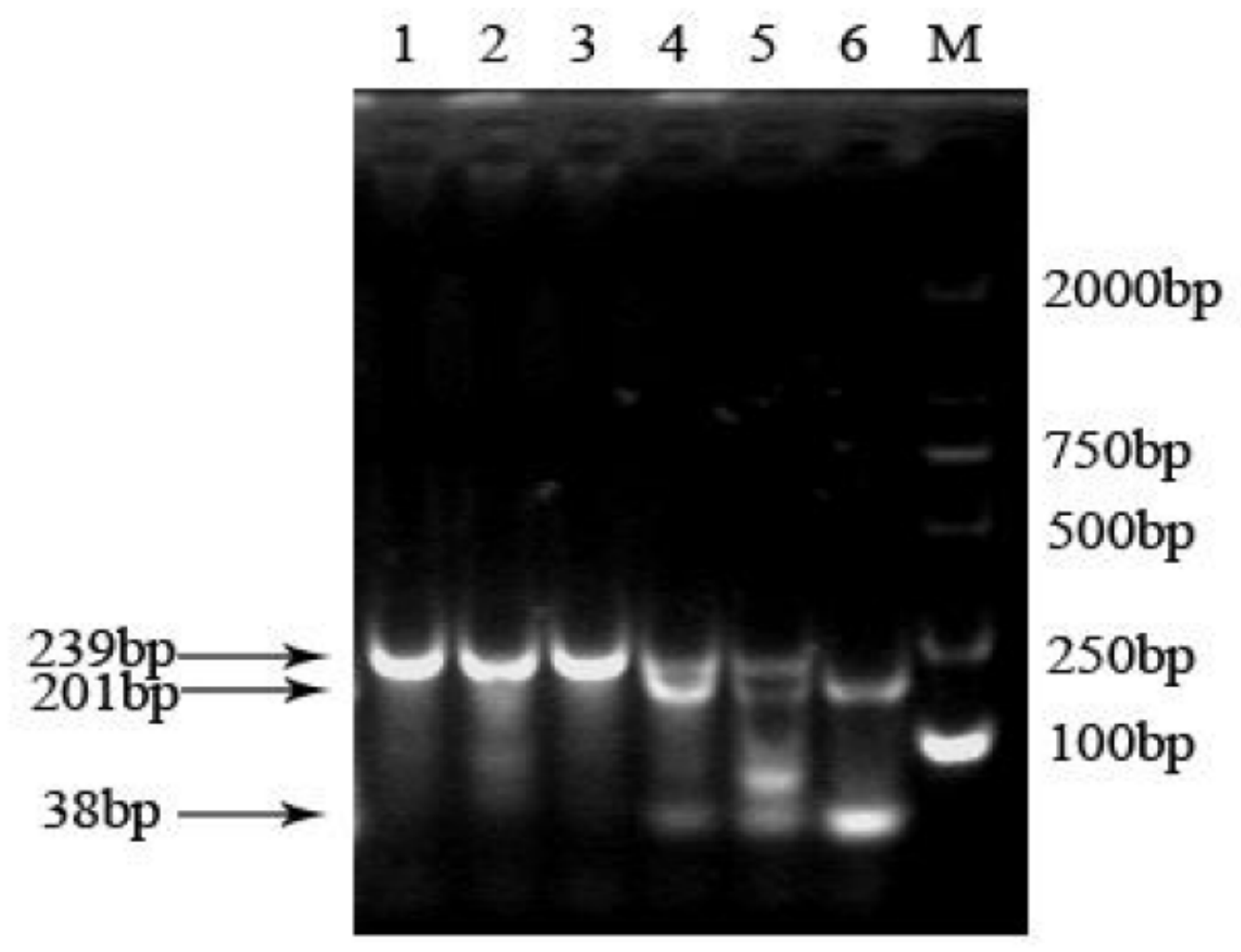

Lane M, 2000 bp marker ladder; lanes 1-3, TT genotype (bands at 239 bp); lanes 4-5, TC genotype (bands at 239-, 201- and 38 -bp); and lanes 6s CC genotype (bands at 201and 38-bp).

\section{Figure 1}

Genotyping of the PPAR $\delta-87 T>C$ polymorphism.

A $\quad$ B

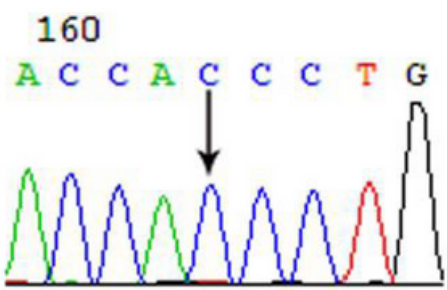

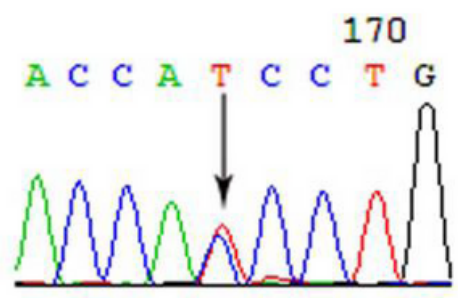

$\mathrm{C}$

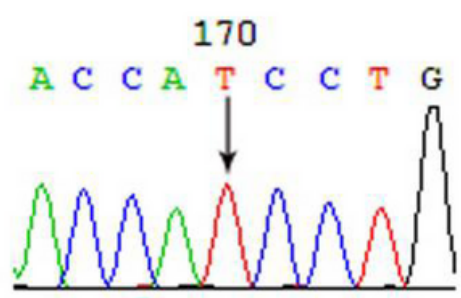

(A) wild-type homozygous TT genotype; (B) heterozygous TC genotype; (C) mutant homozygous CC genotype

Figure 2

A partial PPARס-87T $>C$ polymorphism nucleotide sequence. 


\section{Supplementary Files}

This is a list of supplementary files associated with this preprint. Click to download.

- Table1.pdf

- Table2.pdf

- supplement3.pdf

- supplement4.pdf 